\title{
Endringer i Vær Varsom-plakaten
}

\author{
Ved Henning Herrestad
}

\begin{abstract}
Vær Varsom-plakaten er en viktig rettesnor for journalister, og danner grunnlag for beslutninger i Pressens Faglige Utvalg om hvorvidt media følger presseetiske normer. Norsk Presseforbunds styre vedtok fredag 25.11.2005 flere endringer i Vær Varsom-plakaten, blant annet når det gjelder medienes omtale av selvmord. Endringene trådte i kraft 01.01.2006.
\end{abstract}

Fra 1936 stod det i Vær Varsomplakatens § 4.9: "Selumord eller selumordsforsøk skal som hovedregel ikke omtales."

Det heter i den nye formuleringen: "Vær varsom ved omtale av selvmord og selvmordsforsøk. Unngå omtale som ikke er nødvendig for å oppfylle allmenne informasjonsbehov. Unngå beskrivelse av metode eller andre forhold som kan bidra til a utløse flere selvmordshandlinger".

- Det er altså ikke snakk om noe fritt fram, sier generalsekretær Per Edgar Kokkvold i Presseforbundet, i en pressemelding. - Man plikter å avveie informasjonsbehovet mot både personvernet og faren for "smitte", eller såkalt imiterende selvmordshandlinger. Her har styret valgt å følge klare råd fra fagmiljøene, sier Kokkvold.

Norsk Presseforbund hadde i forhold til endringen av $§ 4.9$ gått til det ekstraordinære skritt å invitere fagmiljøene til å gi høringsuttalelser til det forslaget til endring de hadde sendt ut til sine medlemmer. Det var mange som uttalte seg. Ved SSFF er vi stolte av at det klare råd Kokkvold viser til, kom særlig klart til uttrykk i uttalelsen fra Seksjon for selvmordsforskning og -forebygging. Vi foreslo den ordlyden som ble vedtatt.

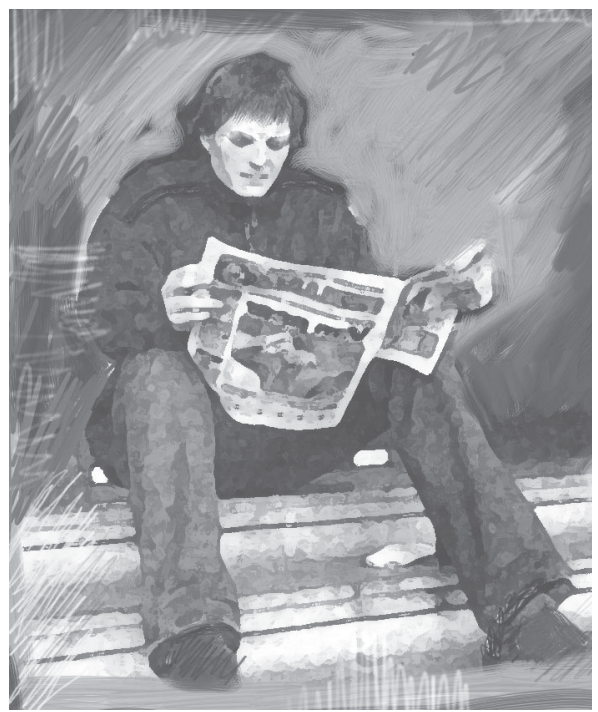

Vi så det som $\varnothing$ nskelig og nødvendig med en liberalisering av den tidligere formulering om at selvmord og selvmordsfors $\varnothing \mathrm{k}$ som hovedregel ikke skal omtales. Vi mener enkelte selvmord har offentlighetens interesse og derfor bør omtales. Vi er positive til en større åpenhet om selvmord og selvmordsfors $\varnothing \mathrm{k}$ fordi det vil svekke den tabuisering, stigmatisering og mytedannelse som i dag er til hinder for å drive selvmordsforebyggende arbeid. Informasjon om selvmordsadferd som et folkehelseproblem, om faresignaler og hvor en kan søke hjelp er viktig forebyggende informasjon.

Setningen "Unngå beskrivelse av metode eller andre forhold som kan bidra til a utløse flere selumordshandlinger" viser til hensynet til faren for smitte eller imiterende selvmordshandlinger. At faren for imiterende selvmordshandlinger er til stede ved medieomtale av selvmord, er vel dokumentert. Vi mener det er meget tungtveiende grunner til å nevne dette hensynet eksplisitt i Vær Varsom-plakaten. Det er viktig at journalistene forstår at formålet med å unngå beskrivelse av metode og lignende forhold er å unngå å utløse flere selvmordshandlinger. Hensynet til personvernet er aktualisert i flere av Vær Varsom-plakatens paragrafer. Hensynet til faren for smitte eller imitasjon er derimot et spesielt hensyn ved omtale av selvmord og selvmordsfors $\varnothing \mathrm{k}$ som for $\varnothing$ vrig ikke er ber $\varnothing \mathrm{rt}$ i plakaten.

Vi selvmordsforskere er særlig opptatte av faren for imiterende selvmordshandlinger fordi denne faren er så grundig dokumentert $\mathrm{i}$ internasjonal forskning. Vi ser dette som en svært alvorlig trussel, og vi har sett flere medieoppslag i Norge i 2005 som aktualiserer denne trusselen. Ett eksempel er saken som ble slått opp i september 2005 om to tenåringsjenter i Frankrike som tok livet av seg ved å hoppe sammen fra en boligblokk. Flere norske aviser gjenga bilder av stedet og omtalte detaljer som at de stod i vinduet, smilte og vinket farvel til kjærestene sine og så hoppet. ${ }^{1}$

Dette er nettopp en type beskrivelse som inviterer til imiterende selvmordsatferd fra andre selvmordsnære personer.

Setningen "Unngå omtale som ikke er nødvendig for å oppfylle allmenne informasjonsbehov" viser til hensynet til personvernet til både avdøde og etterlatte ved selvmord. Det viser også til personvernet til mennesker som er i en personlig krise og har gjort et selvmordsfors $\varnothing \mathrm{k}$. Når det gjelder avdøde, så er det ikke det faktum at personen tok sitt eget liv vi mener det er viktig å unngå å omtale, men derimot omtale som kan bidra til å skade avdødes ettermæle. Eksempler på slik omtale kan være å gi overforenklende årsaksforklaringer på hvorfor personen tok sitt eget liv. Det vil alltid være et mangfold av ulike faktorer som fører til et selvmord, slik at påstander av typen "Mistet jobben, tok sitt eget liv" alltid vil være misvisende. Når det gjelder de etterlatte ved selvmord, kan nærgående spørsmål og kameralinser i en akutt sorgfase medføre risiko for krenkelse av personlige grenser som kan få alvorlige langtidsvirkninger. Som Pressens Faglige Utvalg før har understreket, må mediene unngå å påføre mennesker som allerede befinner seg i en vanskelig livssituasjon, unødige lidelser.

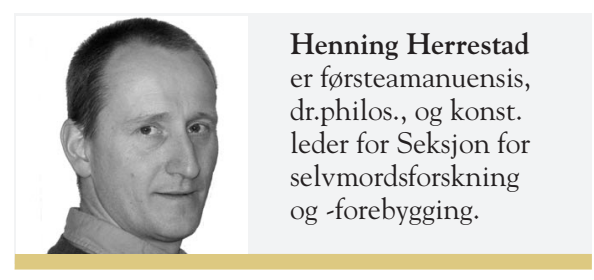

\section{Referanser}

Hawton, K. \& Williams, K. (2002). Influences of the media on suicide. [see comment]. BMJ.325 (7377):1374-5.

Pirkis, J. \& Blood, R. W. (2001). Suicide and the media. Part I: Reportage in nonfictional media. [see comment]. Crisis: Journal of Crisis Intervention \& Suicide.22(4):146-54.

${ }^{1}$ http://www.vg.no/pub/vgart.hbs?artid=107849 http://pub.tv2.no/nettavisen/verden/article463892.ece 